\title{
28 Research Square \\ Medium-chain fatty acids accelerate incorporation of orally applied long-chain polyunsaturated fatty acids into lung tissue
}

Christopher Beermann ( $\nabla$ christopher.beermann@lt.hs-fulda.de)

University of Applied Sciences Fulda: Hochschule Fulda

Daniela Fussbroich

University of Applied Sciences Fulda: Hochschule Fulda

Ralf Schubert

University of Frankfurt: Goethe-Universitat Frankfurt am Main

\section{Short report}

Keywords: asthma, fat metabolic rate, immune response, long-chain polyunsaturated fatty acids, medium chain fatty acids, resolving inflammation, resorption kinetics

Posted Date: December 4th, 2020

DOl: https://doi.org/10.21203/rs.3.rs-120503/v1

License: (a) (1) This work is licensed under a Creative Commons Attribution 4.0 International License. Read Full License 


\section{Abstract}

\section{Background}

Long-chain polyunsaturated fatty acids (LCPUFA) are discussed to resolve chronic inflammation in asthma and other lung diseases. This study aimed at accelerating the incorporation kinetic of orally applied LCPUFA into lung tissue by co-applying medium-chain fatty acids (MCFA) which enhance the fatmetabolic rate.

\section{Methods}

Female C57BL/ 6 mice were orally supplemented with $700 \mathrm{mg}$ eicosapentaenoic acid (EPA, C20:5n3) (group size: $\mathrm{n}=16$ ) or additionally with $300 \mathrm{mg}$ coconut oil with $4.2 \mathrm{wt} \%$ MCFA of total fat per kg body weight per day (group size: $\mathrm{n=16}$ ) for 28 days. The fatty acid profile alterations of lung tissues were monitored by fatty acid methylester-analysis with capillary gaschromatography-flame-ionization detection over 63 days.

Results

The combined administration of EPA with MCFA increased its incorporation into the lung tissue up to day 28 (EPA $1.28 w t \% \pm 0,18$; EPA and MCFA $1.83 w t \% \pm 0.17 ; \Delta 0.55 ; p<0.001$ at day 28). But also its removal thereon was boosted compared to EPA supplementation alone (EPA $0.81 \mathrm{wt} \% \pm 0.08$; EPA and MCFA $0.58 w t \% \pm 0.06 ; \Delta 0.23 ; p<0.001$ at day 31$)$.

\section{Conclusion}

Based on the illustrated accelerating effects of MCFA on the incorporation and removal kinetics of dietary LCPUFA into lung tissue, the present study suggests a two-phase strategy for immune-regulative dietary LCPUFA-supplementation. At the very beginning supplementations should be accompanied with MCFA to support the LCPUFA-uptake, thereon MCFA should be omitted to stabilize the LCPUFA-status in the body.

\section{Full Text}

This preprint is available for download as a PDF.

\section{Figures}




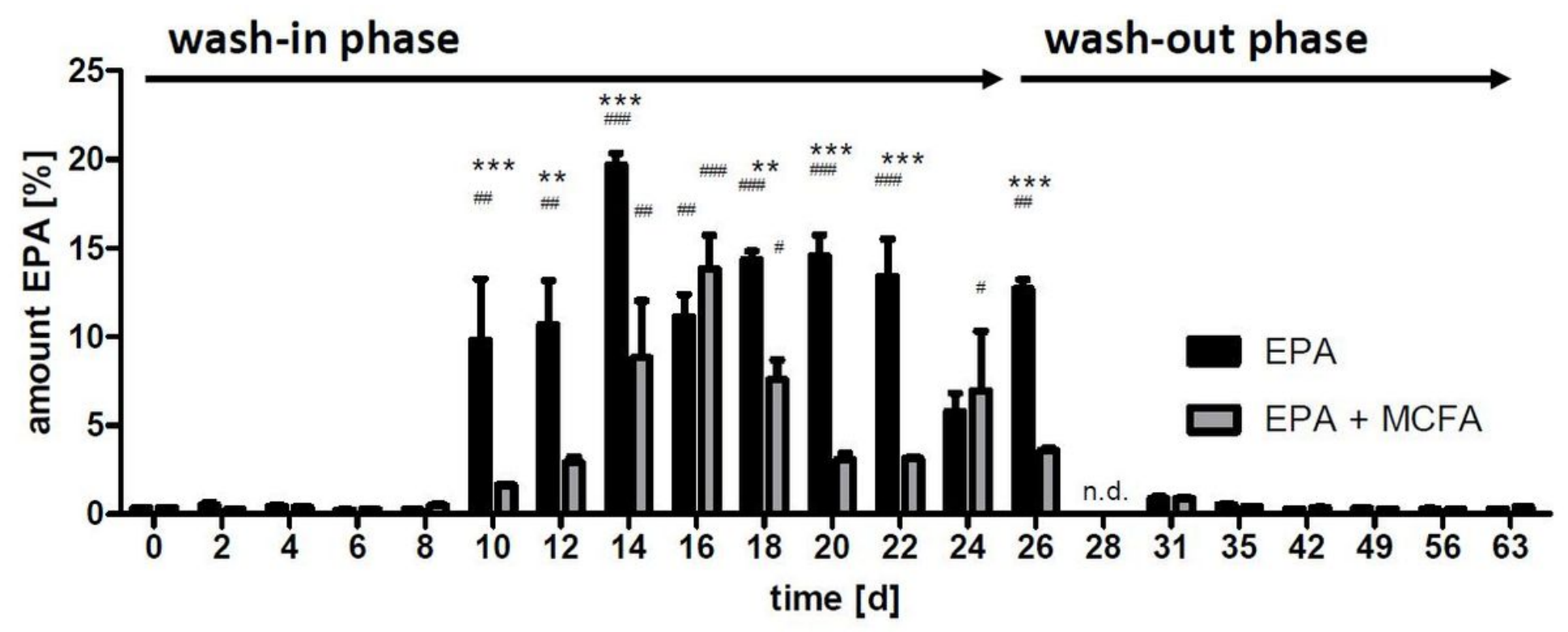

Figure 1

EPA concentration in blood

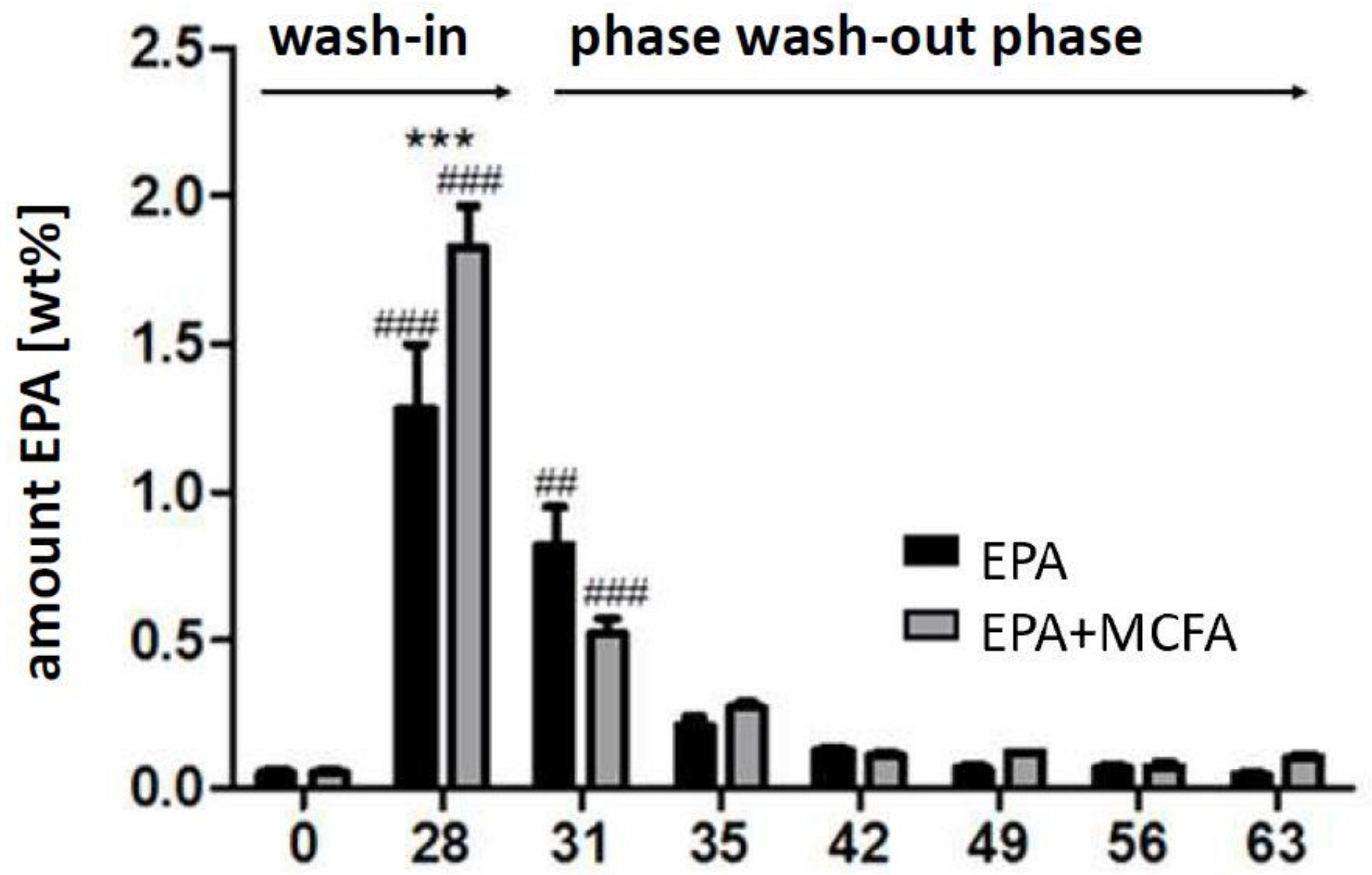

Figure 2

EPA incorporated into lung cells 